DOI: 10.15290/aipan.2020.05

\title{
Rola pracownika socjalnego w orzekaniu o stopniu niepełnosprawności
}

\author{
Alina Miruć \\ Akademia Ekonomiczno-Humanistyczna w Warszawie \\ a.miruc@wp.pl \\ ORCID: https://orcid.org/0000-0002-7373-7033
}

\section{Wprowadzenie}

Z uwagi na powszechność i rozmiar zjawiska niepełnosprawność jest jednym z ważniejszych problemów współczesnego świata. Niepełnosprawność fizyczna wiąże się zazwyczaj z tzw. niepełnosprawnością społeczną, czyli niemożnością pełnego funkcjonowania $\mathrm{w}$ społeczeństwie.

Tytułem prawnym uprawniającym osoby niepełnosprawne do uzyskania świadczeń społecznych, dostępu do rehabilitacji czy mozliwosci podejmowania zatrudnienia jest rozstrzygnięcie właściwego organu administracji publicznej (decyzja administracyjna) ${ }^{1}$. Do tychże organów w świetle ustawy z dnia 27 sierpnia $1997 \mathrm{r}$. o rehabilitacji zawodowej i społecznej oraz zatrudnianiu osób niepełnosprawnych zaliczane są powiatowe lub miejskie zespoły do spraw orzekania o niepełnosprawności - jako pierwsza instancja oraz wojewódzkie zespoły do spraw niepełnosprawności - jako druga instancja². Obok zespołów obu szczebli funkcjonuje również Pełnomocnik Rządu do Spraw Osób Niepełnosprawnych jako organ nadzoru³

W literaturze wskazuje się, że można wyróżnić dwie istotne cechy postępowań przed zespołami do spraw orzekania o niepełnosprawności: odwołanie przysługuje

\footnotetext{
1 W. Maciejko, Sądowa kontrola rozstrzygnięć w sprawach niepełnosprawności, „Administracja. Teoria. Dydaktyka. Praktyka" 2006, nr 1(2), s. 66.

2 Tekst jedn. Dz.U. z 2020 r. poz. 426, zwana dalej ustawą o rehabilitacji, art. 6 ust. 1.

3 Pełni on również rolę swoistego rzecznika praw osób niepełnosprawnych, gdyż ma prawo do inicjowania przed właściwym zespołem nadzwyczajnych postępowań administracyjnych służących wzruszeniu niezgodnych z prawem rozstrzygnięć ostatecznych.
} 
tylko od części orzeczeń, zaś od każdego orzeczenia wojewódzkiego zespołu przysługuje odwołanie do sądu pracy i ubezpieczeń społecznych ${ }^{4}$.

Na mocy ustawy o rehabilitacji wprowadzono system orzekania o niepełnosprawności dla celów pozaubezpieczeniowych. Orzecznictwo o stopniu niepełnosprawności jest adresowane do bardzo szerokiego kręgu podmiotów prawa, gdyż z wnioskiem o ustalenie stopnia mogą występować także osoby posiadające prawomocne przeczenia organów rentowych ZUS i KRUS. Zmiany ustawowe wprowadzone w styczniu 2002 r. poszerzyły ten krąg o osoby, które nie ukończyły 16. roku życia ${ }^{5}$. Opiekunowie tych osób, ubiegając się o ustalenie uprawnień do zasiłku pielęgnacyjnego czy stałego, powinny legitymować się orzeczeniem o niepełnosprawności dziecka $\mathrm{z}$ odpowiednimi wskazaniami.

Celem postępowania o ustalenie stopnia niepełnosprawności jest dokonanie oceny stanu zdrowia konkretnego wnioskodawcy, zgodnie z obowiązującymi kryteriami medycznymi dla celów pozarentowych, takich jak: odpowiednie zatrudnienie, szkolenie, zatrudnienie w zakładzie aktywności zawodowej, uczestnictwa w terapii zajęciowej, konieczności zaopatrzenia w przedmioty ortopedyczne i środki pomocnicze, a także korzystanie $\mathrm{z}$ systemu środowiskowego wsparcia.

Postępowanie o ustalenie niepełnosprawności i stopnia niepełnosprawności jest postępowaniem administracyjnym $\mathrm{z}$ odrębnościami wynikającymi z ustawy o rehabilitacji i wydanego na jej podstawie rozporządzenia Ministra Gospodarki, Pracy i Polityki Społecznej z dnia 15 lipca 2003 r. w sprawie orzekania o niepełnosprawności i stopniu niepełnosprawności ${ }^{6}$.

W niniejszym opracowaniu zostanie przybliżona problematyka orzecznicza w kontekście roli, jaką odgrywa pracownik socjalny w procesie orzekania, mającego na celu ustalenie stopnia niepełnosprawności przewidzianego przez obowiązujące prawo.

\section{Pracownik socjalny w systemie pomocy społecznej}

Pracownicy socjalni, jako bezpośredni realizatorzy zadań w dziedzinie pomocy społecznej, mają istotny wpływ na sprawność działań administracji publicznej, także orzeczniczych w tej sferze, na rzecz osób (rodzin) potrzebujących. Winni być oni profesjonalni, etyczni i skuteczni ${ }^{7}$.

W. Maciejko, Sądowa kontrola rozstrzygnięć..., s. 69.

Rozporządzenie Ministra Pracy i Polityki Społecznej z dnia 1 lutego 2002 r. w sprawie kryteriów oceny niepełnosprawności u osób w wieku do 16. roku życia (Dz.U. z 2002 r. Nr 17, poz. 162).

Tekst jedn. Dz.U. z 2015 r. poz. 1110.

Niewątpliwie przeszkodą i zarazem istotnym mankamentem jest brak odrębnej ustawy o pracownikach socjalnych, która uregulowałaby jednolicie ich status prawny, podniosłaby jakość ich działań oraz zagwarantowałaby temu zawodowi status zawodu zaufania publicznego. 
Rola pracownika socjalnego w orzekaniu o stopniu niepełnosprawności

Charakter wykonywanych zadań $\mathrm{w}$ sferze pomocy społecznej przez pracowników oraz ich szerokie spektrum i znaczenie, wymagające wysokich kwalifikacji (zarówno wiedzy, jak i umiejętności), wyższych niż przeciętnie wymogów etycznych oraz dużego zaufania osób korzystających ze świadczeń pomocy społecznej, przemawiające za uznaniem go za zawód zaufania publicznego ${ }^{8}$. Zawód pracownika socjalnego posiada zakres atrybutów, które cechują zawody zaufania publicznego. Pierwszym warunkiem uznania zawodu za zawód zaufania publicznego jest stwierdzenie, iż jego wykonywanie polega na świadczeniu pomocy innym ludziom z reguły w sytuacjach występowania zagrożenia dla rozmaitych dóbr o istotnej dla nich wartości. Zatem świadczenie tego rodzaju pomocy traktowane jest jako funkcja publiczna. Po drugie, wykonywanie tego zawodu jest nierozerwalnie związane z przyjmowaniem informacji dotyczących sfery życia osobistego, a nawet intymnego innych ludzi. Powierzone im informacje stanowią tajemnicę zawodową. Regulacje prawne winny stwarzać warunki stabilizowania się tego zaufania. Muszą również występować wysoko postawione wymagania przez prawo, które chroniłyby dostęp do wykonywania zawodu zaufania publicznego. Zatem istotne są nie tylko kwalifikacje, lecz zawód ten cechować ma również wysoki poziom etyczny.

Profesjonalizacja i kwalifikacje pracowników socjalnych są istotne, gdyż katalog ich zadań w zakresie pomocy społecznej jest obszerny i zróżnicowany9. Dyferencjacja pozycji prawnej pracowników socjalnych jest uzależniona przede wszystkim od miejsca ich pracy. Jednolite pozostają wymagania dotyczące kwalifikacji, praw i obowiązków, choć wyraźnie odczuwalny jest brak odrębnej ustawy o pracownikach socjalnych. Do zaistniałej sytuacji należy odnieść się krytycznie.

Służby społeczne w ujęciu współczesnym przeznaczone są nie tylko dla potrzebujących pomocy materialnej, inny też wymiar ma obecnie praca socjalna jako działalność zawodowa pracowników socjalnych, która sprostałyby nowym wymaganiom społeczeństwa i prawa. Ustaliłam, że w wielu europejskich systemach kształcenia pracowników socjalnych, także w Polsce, krystalizuje się tendencja do eksponowania wykształcenia ogólnego i wzrostu roli specjalizacji na poziomie kolegiów, studiów wyższych oraz podyplomowych ${ }^{10}$. O profesjonalizacji pracy socjalnej w Europie i na świecie świadczy również konstytuowanie się zawodu pracownika socjalnego w przepisach prawa. Wynika to przede wszystkim $\mathrm{z}$ wpisania go do rejestru zawodów, określenie funkcji i zadań oraz umiejętności i kompetencji.

8 Trafność powyższych tez wykazano w artykule A. Miruć, Pracownik socjalny - zawód zaufania publicznego?, „Administracja. Teoria. Dydaktyka. Praktyka” 2007, nr 2(7), s. 84-105.

9 Szczegółowo określa je ustawodawca w Ustawie z dnia 12 marca 2004 r., o pomocy społecznej. Zob. A. Miruć Profesjonalizacja w zawodzie pracownika socjalnego a potrzeby współczesnej administracji pomocy społecznej (przykład polski), [w:] Administracja wobec wyzwań kryzysu ekonomicznego i jego konsekwencji społecznych, red. W. Mikułowski, A. Jezierska, Warszawa 2014, s. 317-335.

10 A. Miruć, Kształcenie w zawodzie „pracownik socjalny” w wymiarze europejskim, „Administracja.Teoria. Dydaktyka. Praktyka" 2010, nr 3(12), s. 104-127. 
Bez wątpienia istotną rolę wypełniają normy etyczne, które są wyznacznikami działań pracowników socjalnych, także w postępowaniu mającym na celu ustalenie stopnia niepełnosprawności, i wiążą ich bezwzględnie. Ich naruszenie pociąga odpowiedzialność prawną (służbową, porządkową i dyscyplinarną). W sytuacji, gdy normy takie nie zostały wyrażone $\mathrm{w}$ przepisach prawa stanowionego, obowiązują w sumieniu, zaś ich naruszenie pociąga za sobą odpowiedzialność moralną. Zasady odpowiedzialności etycznej pracowników socjalnych określają kodeksy etyczne, będące nie tylko zbiorem nakazów i zakazów, których należy przestrzegać, lecz również mają one przekazywać istotne wartości, takie jak: działanie na rzecz dobra wspólnego, poprawę warunków bytu osób (rodzin), działania na rzecz urzeczywistnienia sprawiedliwości społecznej w procesie stanowienia prawa ${ }^{11}$.

\section{Status prawny osoby niepełnosprawnej a społeczne kryterium niepełnosprawności}

Prawa osób niepełnosprawnych uregulowane zostały w Konstytucji RP z dnia 2 kwietnia 1997 r., która zakazuje dyskryminacji osób niepełnosprawnych, a także zapewnia im wolność wyboru zawodu i miejsca pracy. Na podstawie art. 69 Konstytucji osoby niepełnosprawne mogą liczyć na pomoc ze strony władz publicznych w zabezpieczeniu egzystencji i w przysposobieniu do pracy ${ }^{12}$.

W sposób kompleksowy problematyka niepełnosprawności znalazła uregulowanie w ustawie o rehabilitacji. Zgodnie z jej postanowieniami „niepełnosprawność oznacza trwałą lub okresową niezdolność do wypełniania ról społecznych z powodu stałego lub długotrwałego naruszenia sprawności organizmu, w szczególności powodującą niezdolność do pracy"13.

W świetle obowiązującego prawa instytucją odpowiedzialną w Polsce za umożliwienie osobom niepełnosprawnym samodzielnego funkcjonowania w społeczeństwie jest pomoc społeczna. Jej zadania są wykonywane przez samorząd terytorialny oraz organy administracji rządowej, które mogą i powinny współpracować z licznymi organizacjami sektora pozarządowego.

Niepełnosprawność wymieniana jest w ustawie o pomocy społecznej ${ }^{14}$ jako jedna z kilkunastu przykładowych trudnych sytuacji życiowych (dysfunkcji), uprawniających do korzystania ze świadczeń zarówno o charakterze materialnym,

11 A. Miruć, Odpowiedzialność etyczna pracowników socjalnych, [w:] Odpowiedzialność administracji i w administracji, red. M. Stahl, Z. Duniewska, Warszawa 2013, s. 322-340.

12 Dz.U. z 1997 r. Nr 78, poz. 483.

13 Artykuł 2 pkt 10 ustawy o rehabilitacji.

14 Artykuł 7 ustawy z dnia 12 marca 2004 r. o pomocy społecznej (tekst jedn. Dz.U. z 2019 r. poz. 1507 z późn. $\mathrm{zm}$.). 
Rola pracownika socjalnego w orzekaniu o stopniu niepełnosprawności

jak i niematerialnym. Pomoc społeczna powinna mobilizować, wspierać aktywność, przywracać do samodzielnego funkcjonowania w strukturach społecznych ${ }^{15}$. Stanisław Nitecki słusznie dodaje, że przesłanka ta niekiedy zakresowo pokrywa się z innymi przesłankami, przede wszystkim alkoholizmem, narkomanią czy też długotrwałą chorobą ${ }^{16}$.

Prawnym potwierdzeniem niepełnosprawności pozwalającym na zaliczenie do osób niepełnosprawnych jest orzeczenie o stopniu niepełnosprawności oraz orzeczenie o niepełnosprawności. Wyodrębnia się na gruncie ustawy o rehabilitacji trzy stopnie niepełnosprawności: znaczny, umiarkowany i lekki. W przypadku orzeczenia o stopniu niepełnosprawności przepisy ustawy przewidują więc gradację niepełnosprawności poprzez określenie jej stopni: znacznego, umiarkowanego, lekkiego ${ }^{17}$.

Do lekkiego stopnia niepełnosprawności zalicza się osoby o naruszonej sprawności organizmu, powodującej w sposób istotny obniżenie zdolności do wykonywania pracy w porównaniu do zdolności, jaką wykazuje osoba o podobnych kwalifikacjach zawodowych z pełną sprawnością psychiczną i fizyczną lub mająca ograniczenia w pełnieniu ról społecznych, dające się kompensować przy pomocy wyposażenia w przedmioty ortopedyczne, środki pomocnicze lub środki techniczne ${ }^{18}$.

W związku z powyższym do lekkiego stopnia niepełnosprawności zalicza się następujące grupy osób: osoby o naruszonej sprawności organizmu, powodującej w sposób istotny obniżenie zdolności do wykonywania pracy w porównaniu do zdolności, jaką wykazuje osoba o podobnych kwalifikacjach zawodowych z pełną sprawnością psychiczną i fizyczną; osoby o naruszonej sprawności organizmu, mające ograniczenia $\mathrm{w}$ pełnieniu ról społecznych, dające się kompensować przy pomocy wyposażenia w przedmioty ortopedyczne, środki pomocnicze lub środki techniczne.

Nie ma wymogu, aby powyższe przesłanki występowały łącznie. Obowiązujące kryteria i standardy postępowania orzeczniczego budowane są na konstrukcji określającej zachowane - mimo naruszonej sprawności organizmu - możliwości osoby w zakresie: samodzielnej egzystencji, pełnienia ról społecznych, zatrudnienia w odpowiednich warunkach.

15 R. Gabryszak, D. Magierek, Wprowadzenie do polityki społecznej, Warszawa 2009, s. 226-228.

16 S. Nitecki, Prawo do pomocy społecznej w polskim systemie prawnym, Warszawa 2008, s. 168; S. Nitecki, Komentarz do ustawy o pomocy społecznej, Wrocław 2013, s.119.

17 Artykuł 3 ust. 1 ustawy o rehabilitacji.

18 Artykuł 4 ust. 3 ustawy o rehabilitacji. 
Natomiast do umiarkowanego stopnia niepełnosprawności zalicza się osoby $\mathrm{z}$ naruszoną sprawnością organizmu, niezdolną do pracy albo zdolną do pracy jedynie w warunkach pracy chronionej lub wymagającą czasowej albo częściowej pomocy innych osób $\mathrm{w}$ celu pełnienia ról społecznych ${ }^{19}$. W odniesieniu do ograniczeń w zatrudnieniu definicja umiarkowanego stopnia niepełnosprawności nie różni się od definicji stopnia znacznego. W obu przypadkach występuje kryterium niezdolności do pracy lub kryterium zdolności do pracy jedynie w warunkach pracy chronionej.

Kolejnym kryterium kwalifikującym do umiarkowanego stopnia niepełnosprawności jest konieczność czasowej albo częściowej pomocy innych osób w celu pełnienia ról społecznych. Użyty $\mathrm{w}$ definicji umiarkowanego stopnia niepełnosprawności wyraz „lub” oznacza, że w przeciwieństwie do znacznego stopnia niepełnosprawności każda z przesłanek stanowi samodzielną podstawę do zaliczenia do umiarkowanego stopnia niepełnosprawności.

W konsekwencji do umiarkowanego stopnia niepełnosprawności mogą być zaliczone trzy grupy osób z naruszoną sprawnością organizmu, tj.: niezdolne do pracy, zdolne do pracy jedynie w warunkach pracy chronionej, wymagające czasowej albo częściowej pomocy innych osób w celu pełnienia ról społecznych. Zaliczenie osoby zainteresowanej do umiarkowanego stopnia niepełnosprawności nie wyklucza możliwości zatrudnienia tej osoby u pracodawcy niezapewniającego warunków pracy chronionej na tych samych zasadach jak w przypadku osoby ze znacznym stopniem niepełnosprawności.

Do znacznego zaś stopnia niepełnosprawności zalicza się osoby z naruszoną sprawnością organizmu, niezdolną do pracy albo zdolną do pracy jedynie $\mathrm{w}$ warunkach pracy chronionej i wymagającą - w celu pełnienia ról społecznych - stałej lub długotrwałej opieki i pomocy innych osób w związku z niezdolnością do samodzielnej egzystencji ${ }^{20}$. Oznacza to, że do znacznego stopnia niepełnosprawności zalicza się osoby z naruszoną sprawnością organizmu, które są niezdolne do pracy albo zdolne do pracy jedynie $\mathrm{w}$ warunkach pracy chronionej. Zaliczenie zaś osoby zainteresowanej do znacznego stopnia niepełnosprawności nie wyklucza możliwości zatrudnienia tej osoby u pracodawcy, który nie zapewnia warunków pracy chronionej, w przypadkach uzyskania pozytywnej opinii Państwowej Inspekcji Pracy o przystosowaniu przez pracodawcę stanowiska pracy do potrzeb osoby niepełnosprawnej czy też zatrudnienia w formie telepracy.

Zarówno osoby o znacznym, jak i umiarkowanym stopniu niepełnosprawności muszą jednocześnie wymagać stałej lub długotrwałej opieki i pomocy innych osób

19 Artykuł 4 ust. 2 ustawy o rehabilitacji. 
Rola pracownika socjalnego w orzekaniu o stopniu niepełnosprawności

w celu pełnienia ról społecznych w związku z niezdolnością do samodzielnej egzystencji. Zaliczenie do znacznego stopnia niepełnosprawności możliwe jest bowiem wówczas, gdy u konkretnej osoby występują jednocześnie ograniczenia w wykonywaniu zatrudnienia i konieczność stałej lub długotrwałej opieki i pomocy.

Celem orzecznictwa o niepełnosprawności jest ocena funkcjonalna dotycząca udziału osób w życiu społeczno-zawodowym.

\section{Składy orzekające powiatowych i wojewódzkich zespołów do spraw orzekania o niepełnosprawności}

U podstaw wprowadzenia kolegialnego orzekania o niepełnosprawności leżało przeświadczenie, że taki tryb orzekania zwiększy możliwość właściwego rozpoznawania potrzeb zawodowych i społecznych osób, których dotyczy orzeczenie, co w konsekwencji zwiększy szansę na aktywne włączenie ich w nurt życia społecznego i zawodowego oraz zapobiegnie wykluczeniu społecznemu.

W postępowaniu orzeczniczym uczestniczą specjaliści reprezentujący następujące kategorie zawodowe: lekarze, psychologowie, pracownicy socjalni, pedagodzy, doradcy zawodowi. Wniosek o ustalenie niepełnosprawności bądź stopnia niepełnosprawności rozpatruje co najmniej dwuosobowy skład orzekający. Z posiedzenia w sprawie wydania orzeczenia sporządza się protokół. Przewodniczącym składu orzekającego jest zawsze lekarz ${ }^{21}$.

Postępowanie w sprawie orzekania o niepełnosprawności i stopniu niepełnosprawności, przewidziane w rozdziale 2 ustawy o rehabilitacji, obejmuje: zebranie materiału dowodowego dotyczącego naruszenia sprawności organizmu, możliwości funkcjonowania w życiu codziennym i pełnieniu ról społecznych; dokonanie przez lekarza wyznaczonego przez przewodniczącego zespołu wstępnej weryfikacji złożonej dokumentacji w zakresie jej kompletności i ewentualnego uzupełnienia o badania potwierdzające rozpoznaną chorobę zasadniczą, a także określenie specjalności przewodniczącego składu orzekającego odpowiedniej do rozpoznanych schorzeń osoby zainteresowanej lub dziecka; powołanie spośród członków zespołu składu orzekającego do rozpoznania wniosku i wydania orzeczenia - w razie potrzeby powołuje się dodatkowo specjalistę odpowiedniego do choroby współistniejącej, mogącej mieć istotny wpływ na wynik postępowania orzeczniczego, oraz zarządza kompleksowe dokumentowanie stanu zdrowia i sytuacji społecznej osoby zainteresowanej lub dziecka.

21 Rozporządzenie Ministra Pracy i Polityki Społecznej z dnia 18 grudnia 2007 r. w sprawie wykonywania badań specjalistycznych na potrzeby orzekania o niepełnosprawności i stopniu niepełnosprawności (Dz.U. z 2007 r. Nr 250, poz. 1875). 
W 2011 r. Biuro Pełnomocnika Rządu do Spraw Osób Niepełnosprawnych przedstawiło propozycje kryteriów doboru członków zespołów do spraw orzekania o niepełnosprawności do składu orzekającego. Pracownik socjalny powinien być wyznaczany do składu obligatoryjnie w przypadku:

- orzekania wobec osób, u których rozpoznano chorobę zasadniczą: zaburzenia głosu, mowy i choroby słuchu, choroby narządu wzroku, upośledzenie narządu ruchu, choroby układu oddechowego i krążenia, choroby układu pokarmowego, choroby układu moczowo-płciowego, choroby neurologiczne, choroby enzymatyczne, choroby zakaźne i odzwierzęce, zeszpecenia, choroby układu krwiotwórczego - bez względu na wiek, jeżeli wykonują pracę zarobkową i wystąpiły $\mathrm{z}$ wnioskiem o wydanie orzeczenia o stopniu niepełnosprawności w celach innych niż szkolenie i odpowiednie zatrudnienie;

- orzekania wobec osób, u których rozpoznano chorobę zasadniczą taką jak wyżej wymienione w wieku powyżej 59. roku życia, niewykonujących pracy zarobkowej, jeżeli wystąpiły z wnioskiem o wydanie orzeczenia o stopniu niepełnosprawności w celach innych niż szkolenie i odpowiednie zatrudnienie;

- fakultatywnie z doradcą zawodowym w przypadku osób, u których rozpoznano chorobę zasadniczą (jedną z ww. wymienionych) w wieku od 18. do 59. roku życia, niewykonujących pracy zarobkowej, jeżeli wystąpiły z wnioskiem o wydanie orzeczenia o stopniu niepełnosprawności w celach innych niż szkolenie i odpowiednie zatrudnienie.

\section{Rola pracownika socjalnego jako szczególnego specjalisty w sprawach społecznych}

Pracownik socjalny musi posiadać wysokie kwalifikacje (kryterium jest posiadanie dyplomu szkoły pracowników socjalnych lub ukończone studia wyższe w wyższej szkole zawodowej o specjalności praca socjalna, lub studia wyższe na kierunkach: pedagogika, politologia i nauki społeczne, psychologia, socjologia, lub ukończone studia wyższe na innych kierunkach i specjalizacja z zakresu pracy socjalnej lub organizacji pomocy społecznej uzyskana w trybie określonym w przepisach o pomocy społecznej). Członek powiatowego bądź wojewódzkiego zespołu, biorąc udział w posiedzeniu składu orzekającego, sporządza ocenę, w której określa w szczególności: występujące ograniczenia w zdolności do samodzielnej egzystencji i pełnieniu ról społecznych, stopień uzależnienia od innych osób w codziennym funkcjonowaniu czy tez zakres koniecznej opieki lub pomocy innych osób oraz systemu środowiskowego wsparcia w samodzielnej egzystencji.

Katalog zadań pracownika socjalnego jest obszerny i zróżnicowany. Konkretne obowiązki dostosowane są do wymagań jednostki zatrudniającej i specyfiki wykonywanej pracy. Każdy pracownik socjalny powinien posiadać umiejętności prawi- 
Rola pracownika socjalnego w orzekaniu o stopniu niepełnosprawności

dłowego rozpoznawania sytuacji osób i rodzin korzystających z pomocy społecznej, zaplanowania odpowiednich do danego przypadku form pomocy oraz monitorowania i dokonywania ewaluacji podejmowanych działań ${ }^{22}$.

$\mathrm{W}$ świetle aktualnie obowiązujących aktów prawnych pracownik socjalny w zakresie orzekania o stopniu niepełnosprawności zobowiązany jest do: zebrania materiału dowodowego dotyczącego skutków naruszonej sprawności organizmu oraz braku możliwości lub występujących ograniczeń w samodzielnym funkcjonowaniu w życiu codziennym i pełnieniu ról społecznych; stworzenia wnikliwej i rzetelnej oceny społecznej poprzez przeprowadzenie rozmowy z orzekaną osobą, przy zachowaniu i poszanowaniu dóbr osobistych, stosując przyjęte dla pracowników socjalnych techniki, takie jak: wywiad - zaplanowana i ukierunkowana rozmowa oraz obserwacja - zamierzone spostrzeganie, analiza zgromadzonych dokumentów; sporządzenia oceny społecznej - trafnej, merytorycznie spójnej wewnętrznie, zgodnej z obowiązującymi standardami; udziału w posiedzeniu składu orzekającego - w celu wypracowania ostatecznej decyzji.

Stosowane $\mathrm{w}$ postępowaniu orzeczniczym kryterium społeczne odnosi się do oceny utraty możliwości lub ograniczeń uczestnictwa osoby w życiu osobistym i społecznym, zdefiniowanym dla potrzeb procesu orzeczniczego jako niezdolność do samodzielnej egzystencji i pełnienia ról społecznych. Niezdolność lub ograniczenie w pełnieniu ról społecznych oznaczają, iż osoba na skutek naruszonej sprawności organizmu nie spełnia oczekiwań społecznych wyznaczonych przez normy i zwyczaje w zależności od wieku, płci, stanu cywilnego, pozycji zajmowanej w grupie społecznej. Deficyt fizycznej, psychicznej lub umysłowej sprawności organizmu powoduje, że człowiek nie radzi sobie z pełnieniem lub podjęciem określonych ról społecznych, „porzuca” je lub z nich „wypada”. Ograniczenie sprawności powoduje także indywidualne konsekwencje o charakterze społecznym, tj.: zmianę pozycji - z pracownika na osobę bez pracy lub pracującą w ograniczonym zakresie, z osoby decydującej o sprawach rodziny na osobę uzależnioną od pomocy innych itp.; zmianę ekonomiczną - od samodzielności ekonomicznej do ekonomicznego uzależnienia, czyli od sytuacji, gdy człowiek mógł podejmować decyzje dotyczące konkretnych wyborów, do sytuacji, gdy zaspokojenie jego potrzeb bytowych jest zależne od pomocy z zewnątrz - innych osób z rodziny, instytucji; zmianę oczekiwań społecznych i wyznaczenie nowych ról (kulturowo związanych z faktem, że jest się osobą niepełnosprawną) - oczekuje się od takiej osoby podporządkowania innym i uzależnienia od ich decyzji, a także zrezygnowania $\mathrm{z}$ dotychczas pełnionych funkcji. 
Możliwość pełnienia ról społecznych uzależniona jest od stopnia naruszenia sprawności organizmu ograniczającego możliwości samodzielnej egzystencji. Stopień niezdolności do samodzielnej egzystencji jest więc kryterium oceny społecznej $\mathrm{w}$ postępowaniu o ustalenie niepełnosprawności, która w dużej mierze ogranicza możliwości pełnienia ról społecznych. Występujące ograniczenia sprawności prowadzą do konkretnych trudności w życiu i stanowią wymierną przeszkodę w rozwoju ${ }^{23}$. Sporządzenie tzw. oceny społecznej powinno być poprzedzone dokładną i pogłębioną analizą przedłożonej przez osobę wnioskującą o ustalenie stopnia niepełnosprawności dokumentacji i informacji zawartych we wniosku, dotyczących celu, dla którego osoba ubiega się o uzyskanie prawnego statusu niepełnosprawności, sytuacji rodzinnej i środowiskowej, aktywności zawodowej i społecznej oraz informacji o ewentualnych uprawnieniach wynikających z systemów rentowych. $\mathrm{Na}$ kolejnym etapie procesu orzeczniczego pracownik socjalny powinien przeprowadzić bezpośrednią rozmowę z osobą, której postępowanie dotyczy (i ewentualnie $z$ jej opiekunem), wraz z jednoczesną obserwacją - w celu uzyskania informacji niezbędnych do dokonania oceny jej funkcjonowania. W przypadku wątpliwości co do szczerości wypowiedzi powinien je przedyskutować z lekarzem - przewodniczącym składu orzekającego (podczas posiedzenia składu orzekającego).

$\mathrm{Z}$ kolei indywidualna ocena społeczna, opracowana dla potrzeb orzecznictwa o niepełnosprawności, zawiera ustalenia co do ograniczeń lub braku możliwości wykonywania czynności lub zachowań uznanych za normalne i społecznie oczekiwane. Warto przy tym zauważyć, iż do zakresu niezbędnych informacji w procesie orzeczniczym nie należą informacje dotyczące dochodów uzyskiwanych przez osobę orzekaną, jej zasobów majątkowych czy wykazu osób zobowiązanych do alimentacji. Są to kryteria stosowane do przyznania świadczeń pieniężnych przez powołane do tego organy, a orzeczenie o niepełnosprawności lub stopniu niepełnosprawności stanowi jeden z wymogów koniecznych do przyznania świadczenia. Rolą pracownika socjalnego w postępowaniu orzeczniczym jest też zatem ustalenie, czy i w jakim zakresie osoba niepełnosprawna może liczyć na pomoc i konieczne wsparcie ze strony rodziny lub jednostek organizacyjnych pomocy społecznej, a także instytucji i organizacji pozarządowych działających na rzecz pomocy osobom i rodzinom.

Rola pracownika socjalnego polega więc na przedstawieniu oceny socjalnej, wskazującej na związek pomiędzy rozpoznanymi ograniczeniami w sferze funkcjonowania osoby w samodzielnej egzystencji i pełnieniu ról społecznych a proponowanym stopniem niepełnosprawności - zgodnie z definicjami ustawowymi. 
Rola pracownika socjalnego w orzekaniu o stopniu niepełnosprawności

Rozwiązania prawne ustawy o rehabilitacji dają pracownikowi socjalnemu w przypadku niezgodności ocen sporządzonych przez pozostałych specjalistów uczestniczących w postępowaniu orzeczniczym - prawo zgłoszenia zdania odrębnego do protokołu. Wycofanie się ze swoich ustaleń i przyjęcie rozwiązania niezgodnego z przedstawioną oceną socjalną oraz rezygnacja ze zgłoszenia zdania odrębnego powoduje przyjęcie współodpowiedzialności za rozstrzygnięcie ostateczne. Jest to jednocześnie przyjęcie odpowiedzialności za wydanie orzeczenia o stopniu niepełnosprawności lub niepełnosprawności niezgodnego ze stanem faktycznym. Uległość i odstępstwo od własnej rzetelnie i wnikliwie sporządzonej oceny socjalnej podważa znaczenie i rolę, jaką ma do spełnienia pracownik socjalny w postępowaniu orzeczniczym².

Role, cele i zadania pracownika socjalnego spowodowały, iż ustawodawca słusznie przywiązuje istotną wagę do kwalifikacji formalnych (wykształcenia) pracowników socjalnych oraz doskonalenia zawodowego. Aktualne wymagania stawiane pracownikom socjalnym są co raz wyższe i wymagają specjalistycznej wiedzy, umiejętności oraz predyspozycji personalnych. Ważny jest fakt, że osoby zaangażowane w pracę socjalną akceptują potrzebę kształcenia i doskonalenia oraz wyrażają chęć kontynuacji edukacji zawodowej w formie studiów wyższych, kursów specjalistycznych czy też studiów podyplomowych ${ }^{25}$.

Warto podkreślić, że praca pracownika socjalnego to nieustanna nauka o drugim człowieku, ale także wchodzenie w role w szerokim spektrum życia codziennego. Efekty działania pracownika socjalnego mają szczególne znaczenie nie tylko dla jednostek, ale również dla społeczności, w której jednostki te funkcjonują. Celem ich działań jest wzmacnianie osób i rodzin w odzyskiwaniu zdolności samodzielnego funkcjonowania w społeczeństwie, rozwijanie poczucia godności osobistej i odpowiedzialności jednostek, stymulowanie grup i całych społeczności lokalnych ku samopomocy oraz przeciwdziałanie powstawaniu dysfunkcji ${ }^{26}$.

Postępowanie o ustalenie niepełnosprawności jest kolegialne i wymaga od zespołu orzekającego w postępowaniu wiedzy merytorycznej oraz aktywnego udziału w wypracowaniu ostatecznej decyzji zaliczającej osobę do odpowiedniego stopnia niepełnosprawności na posiedzeniu składu orzekającego.

24 W przypadku niezgodności ocen w składzie orzekającym rozstrzyga ocena przewodniczącego składu orzekającego, a członek składu orzekającego zgłasza na piśmie zdanie odrębne wraz z uzasadnieniem. Zgłoszenie zdania odrębnego odnotowuje się w protokole. Należy pamiętać, iż ocena funkcjonowania społecznego osoby orzekanej ma wartość dowodu w sprawie o ustalenie niepełnosprawności lub stopnia niepełnosprawności. Powstaje w następstwie rozmowy pracownika socjalnego z osobą zainteresowaną lub przedstawicielem ustawowym dziecka, przeprowadzonej w warunkach zapewniających dyskrecję, poszanowanie dóbr osobistych i zachowanie poufności. Taki klimat powinien wytworzyć pracownik socjalny w trakcie prowadzonej rozmowy. 


\section{Istotne spostrzeżenia praktyczne}

Służby społeczne w ujęciu współczesnym przeznaczone są nie tylko dla potrzebujących jedynie pomocy materialnej, bowiem inny wymiar ma obecnie praca socjalna jako działalność zawodowa pracowników socjalnych, a to przemawia za kształceniem wysoko wykwalifikowanych kadr, które sprostałyby nowym wymaganiom społeczeństwa i prawa ${ }^{27}$. Dlatego też członek pozamedyczny, jakim jest pracownik socjalny, winien $\mathrm{w}$ swoim postępowaniu w trakcie sporządzania oceny odnosić się nie tylko do zdobytej wiedzy, ale także kierować się wysoką kulturą osobistą i taktem, zwłaszcza przy orzekaniu dotyczącym osób, które mają trudności w precyzyjnym i spójnym formułowaniu swoich myśli.

Należy podkreślić, że rola pracownika socjalnego w postępowaniu orzeczniczym w stosunku do osób, które ukończyły 16. rok życia sprowadza się do oceny ograniczeń, jakie taka osoba doświadcza w życiu codziennym. Sporządzenie oceny społecznej powinno być poprzedzone dokładną analizą przedłożonej przez osobę wnioskującą o ustalenie stopnia niepełnosprawności dokumentacji i informacji zawartych we wniosku dotyczących celu, dla którego osoba ubiega się o uzyskanie prawnego statusu niepełnosprawności, sytuacji rodzinnej i środowiskowej, aktywności zawodowej i społecznej, oraz informacji o ewentualnych uprawnieniach wynikających z systemów rentowych. Kolejnym etapem jest bezpośrednia rozmowa z osobą zainteresowaną, na podstawie której opracowana zostanie ostateczna ocena społeczna niepełnosprawności.

Ocena społeczna dotycząca dzieci wymaga analizy sytuacji rodziny, której jest ono członkiem, ale przede wszystkim ograniczeń w czynnościach, które dziecko powinno wykonywać stosownie do wieku. Podczas przeprowadzania oceny zawsze należy rozmawiać $\mathrm{z}$ dzieckiem. Rodzic - w mojej ocenie - powinien pełnić rolę uściślającą podane fakty, doprecyzować dane dotyczące stanu zdrowia i ograniczeń w życiu codziennym. Uważam, że ważna jest tu postawa partnerska, gdzie dziecko nie siedzi z boku, a rodzic tylko opisuje schorzenia i odpowiada na pytania zawarte w ocenie, ale w pełni, na miarę swoich możliwości, uczestniczy w rozmowie.

W stosunku do osób młodych, które jeszcze nie zdobyły doświadczenia zawodowego, głównym kryterium w kwalifikowaniu do osób niepełnosprawnych jest pełnienie ról społecznych adekwatnych do wieku. Natomiast osoby starsze wymagają dostosowania rozmowy do ich ograniczeń zarówno w zakresie komunikowania się, jak i zdolności do rozumienia mowy. Pytania powinny być zadawane głośno i w sposób zrozumiały dla orzekającego się. Informacje od osoby o jej funkcjonowaniu na poziomie aktywności indywidualnej w zakresie samoobsługi, poruszania się i komunikowania bardzo często sprowadzają się do stwierdzenia, iż osoba ta nie

Ibidem, s. 104. 
Rola pracownika socjalnego w orzekaniu o stopniu niepełnosprawności

może wykonywać samodzielnie praktycznie żadnej z czynności życia codziennego. Oczywiście osoby starsze niewątpliwie doświadczają trudności w pełnieniu ról społecznych, jednak w mojej ocenie nie są one całkowicie uzależnione od otoczenia w samodzielnej egzystencji. Pomoc, jakiej potrzebują, często sprowadza się do wyręczenia ich w pracach fizycznych, zrobieniu porządków czy też dowiezieniu do lekarza specjalisty.

Jedną z przesłanek w postępowaniu orzeczniczym jest niemożność pełnienia ról społecznych, ale adekwatnych do wieku, płci, czynników społecznych i kulturowych. Ważne jest, aby pracownik socjalny w trakcie przeprowadzania rozmowy umiał ocenić faktyczne uzależnienie osoby od innych w samodzielnej egzystencji od subiektywnej oceny możliwości osoby zainteresowanej w codziennym funkcjonowaniu. Osoby starsze zazwyczaj ubiegają się o znaczny stopień niepełnosprawności. Należy jednak pamiętać, iż zakres ograniczeń wynikający ze stwierdzonego schorzenia musi powodować całkowitą zależność osoby od otoczenia w samodzielnej egzystencji w czynnościach samoobsługowych, komunikowaniu się z otoczeniem i samodzielnym poruszaniu się. Przesłanki te muszą wystąpić łącznie, aby dawać podstawę do orzeczenia znacznego stopnia niepełnosprawności.

Należy podkreślić, iż konieczność udzielania pomocy i sprawowanie opieki oznaczają taką zależność osoby od otoczenia, która polega w szczególności na udzielaniu wsparcia i pomocy w czynnościach samoobsługowych, prowadzeniu gospodarstwa domowego, leczeniu, rehabilitacji i edukacji. Pomoc w czynnościach życia codziennego musi wynikać faktycznie z zakresu naruszonej sprawności organizmu, a nie z pomocy udzielanej przez członków rodziny na zasadzie współżycia w rodzinie i uczestnictwa w zwyczajowych stosunkach społecznych.

Rola pracownika socjalnego jako członka pozamedycznego składu orzekającego w tym wypadku jest wielopoziomowa. W procesie orzeczniczym pracownik socjalny musi spojrzeć całościowo na zastany stan faktyczny dotyczący konkretnej osoby, na jej funkcjonowanie nie tylko w społeczeństwie, ale także w życiu lokalnym czy rodzinnym. Osoba niepełnosprawna, chora, zniedołężniała, w podeszłym wieku jest często zdana jedynie na siebie i wskazanie odpowiedniego kierunku wsparcia i pomocy nie leży tylko w gestii osób pracujących w ośrodkach pomocy społecznej, ale także zalicza się do znaczącej roli, jaką odgrywają osoby zajmujące się orzekaniem.

Osoby orzekające w wojewódzkich i powiatowych (miejskich) zespołach, aby być profesjonalistami, nieustannie muszą podnosić kwalifikacje zawodowe ${ }^{28}$. Praca w zespole jest niewątpliwie cennym doświadczeniem. Pozwala na nieustanną kon- 
frontację wiedzy zdobytej na studiach, szkoleniach czy studiach podyplomowych $\mathrm{z}$ realnymi postawami i problemami osób potrzebujących. Daje też możliwość nawiązywania prawidłowych relacji z drugim człowiekiem i udzielenia mu realnej pomocy oraz wsparcia.

Należy podkreślić że system orzekania o niepełnosprawności w Polsce jest krytykowany przez środowisko osób niepełnosprawnych, jak i organizacje działające na rzecz tychże osób. Ze Społecznego Raportu Alternatywnego z wdrażania Konwencji o prawach osób z niepełnosprawnościami w Polsce, opublikowanego w 2015 r. ${ }^{29}$, wynika, że należy stworzyć jeden system orzekania o niepełnosprawności, w którym orzekano by nie jedynie o dysfunkcjach, a o uprawnieniach danej osoby. W zaproponowanym nowym systemie instytucja orzekająca powinna być niezależna od instytucji udzielającej wsparcia. Istnieje konieczność zastąpienia ustawy o rehabilitacji społecznej i zawodowej oraz o zatrudnianiu osób niepełnosprawnych nową ustawą o orzecznictwie o niepełnosprawności oraz o instytucjach i instrumentach wsparcia osób niepełnosprawnych, która kompleksowo ujednolicałaby orzecznictwo w tym zakresie.

Również dla realizacji założeń Nowego Systemu Wsparcia Osób z Niepełnosprawnością, przyjętych przez III Kongres Osób z Niepełnosprawnościami w 2017 r., wynika, że konieczna jest nowa ustawa o orzecznictwie oraz koordynacji wsparcia osób z niepełnosprawnościami, która zastąpiłaby ustawę o rehabilitacji.

Ponadto Rekomendacja Komitetu Praw Osób Niepełnosprawnych ONZ dla Polski z 2018 r. wskazuje na konieczność wprowadzenia w Polsce jednolitego systemu orzekania o niepełnosprawności wypracowanego z udziałem licznych organizacji działających na rzecz osób z niepełnosprawnościami.

\section{Uwagi końcowe}

Opracowanie przybliża zagadnienie szczególnie istotne zarówno z punku widzenia teoretycznego, jak i praktycznego na temat istotnej roli, jaką odgrywa pracownik socjalny w systemie pomocy społecznej, w tym w procesie orzekania o stopniu niepełnosprawności.

W moim przekonaniu pracownik socjalny jako członek pozamedyczny jest tą osobą, która daje pełny obraz funkcjonowania społecznego osoby niepełnosprawnej. Nierozerwalnie współpracuje z lekarzem i dzieli się z nim wiedzą zdobytą podczas przeprowadzania oceny społecznej. Sporządzenie oceny społecznej powinno być poprzedzone dokładną i pogłębioną analizą przedłożonej przez osobę wniosku- 
Rola pracownika socjalnego w orzekaniu o stopniu niepełnosprawności

jącą o ustalenie stopnia niepełnosprawności dokumentacji i informacji zawartych we wniosku dotyczących celu, dla którego osoba ubiega się o uzyskanie prawnego statusu niepełnosprawności, sytuacji rodzinnej i środowiskowej, aktywności zawodowej i społecznej, oraz informacji o ewentualnych uprawnieniach wynikających z systemów rentowych.

Rola pracownika socjalnego w postępowaniu orzeczniczym polega więc na wnikliwym opracowaniu indywidualnej oceny występujących ograniczeń, spowodowanych naruszoną sprawnością organizmu w funkcjonowaniu osoby na poziomie indywidualnym i społecznym (konsekwencje naruszenia sprawności organizmu), oraz stopnia uzależnienia od innych osób w codziennym funkcjonowaniu, wraz z określeniem zakresu i rozmiaru potrzeb wyrażonych we wskazaniach zawartych w orzeczeniu o stopniu niepełnosprawności.

Pracownik socjalny, będąc osobą, która współdecyduje o przyznaniu określonego stopnia niepełnosprawności, przyczynia się przede wszystkim do poprawy nie tylko statusu materialnego takich osób, ale także - i przede wszystkim - do poprawy ich funkcjonowania w społeczeństwie.

Należałoby się odnieść pozytywnie do krytyki systemu orzekania o niepełnosprawności środowiska osób z niepełnosprawnością i propozycji zmian roli pracownika socjalnego w nowym systemie orzekania o niepełnosprawności

\section{Akty prawne}

Konstytucja RP z dnia 2 kwietnia 1997 r. (Dz.U. z 1997 r. Nr 78, poz. 483).

Ustawa z dnia 12 marca 2004 roku o pomocy społecznej (tekst jedn. Dz.U. z 2019 r. poz. 1507 ze zm.).

Ustawa z dnia 27 sierpnia 1997 r. o rehabilitacji zawodowej i społecznej oraz zatrudnianiu osób niepełnosprawnych (tekst jedn. Dz.U. z 2020 r. poz. 426).

Rozporządzenie Ministra Pracy i Polityki Społecznej z dnia 1 lutego 2002 r. w sprawie kryteriów oceny niepełnosprawności u osób w wieku do 16. roku życia (Dz.U. z 2002 r. $\mathrm{Nr}$ 17, poz. 162).

Rozporządzenie Ministra Gospodarki, Pracy i Polityki Społecznej z dnia 15 lipca 2003 r. w sprawie orzekania o niepełnosprawności i stopniu niepełnosprawności (tekst jedn. Dz.U. z 2015 r. poz. 1110).

Rozporządzenie Ministra Pracy i Polityki Społecznej z dnia 28 listopada 2007 r. w sprawie warunków, sposobu oraz trybu gromadzenia i usuwania danych w ramach Elektronicznego Krajowego Systemu Monitoringu Orzekania o Niepełnosprawności (Dz.U. z 2007 r. Nr 228, poz. 1681).

Rozporządzenie Ministra Pracy i Polityki Społecznej z dnia 18 grudnia 2007 r. w sprawie wykonywania badań specjalistycznych na potrzeby orzekania o niepełnosprawności i stopniu niepełnosprawności (Dz.U. z 2007 r. Nr 250, poz. 1875). 
Alina Miruć

Rozporządzenie Ministra Pracy i Polityki Społecznej z dnia 23 grudnia 2009 r. zmieniające rozporządzenie w sprawie orzekania o niepełnosprawności i stopniu niepełnosprawności (Dz.U. z 2009 r. Nr 224, poz. 1803).

\section{Literatura}

Gabryszak R., Magierek D., Wprowadzenie do polityki społecznej, Warszawa 2009.

Maciejko W., Sądowa kontrola rozstrzygnięć w sprawach niepełnosprawności, „Administracja. Teoria. Dydaktyka. Praktyka" 2006, nr 1(2).

Miruć A., Pracownik socjalny - zawód zaufania publicznego?, „Administracja. Teoria. Dydaktyka. Praktyka” 2007, nr 2(7).

Miruć A., Kształcenie w zawodzie „pracownik socjalny” w wymiarze europejskim, „Administracja. Teoria. Dydaktyka. Praktyka" 2010, nr 3(12).

Miruć A., Odpowiedzialność etyczna pracowników socjalnych, [w:] Odpowiedzialność administracji $i$ w administracji, red. M. Stahl, Z. Duniewska, Warszawa 2013.

Miruć A., Profesjonalizacja w zawodzie pracownika socjalnego a potrzeby współczesnej administracji pomocy społecznej (przykład polski), [w:] Administracja wobec wyzwań kryzysu ekonomicznego i jego konsekwencji społecznych, red. W. Mikułowski, A.Jezierska, Warszawa 2014.

Nitecki S., Prawo do pomocy społecznej w polskim systemie prawnym, Warszawa 2008.

Nitecki S., Komentarz do ustawy o pomocy społecznej, Wrocław 2013.

Sierpowska I., Prawo pomocy społecznej, Warszawa 2011.

Zadrożny J. (red.), Społeczny Raport Alternatywny z realizacji Konwencji o prawie osób z niepetnosprawnościami w Polsce, Warszawa 2015. 